\title{
ALAT PEMBANGKIT SUARA ULTRASONIK OTOMATIS UNTUK MERANGSANG PEMBUKAAN STOMATA TANAMAN MENGGUNAKAN MIKROKONTROLER ATMEGA328P YANG DILENGKAPI DENGAN PANEL SURYA
}

\author{
Priguna Septia Putra ${ }^{*}$, Adian Fatchur Rochim ${ }^{1)}$, Eko Didik Widianto ${ }^{1)}$, Mentary Putri Pratami ${ }^{2)}$ \\ 1) Program Studi Sistem Komputer, Fakultas Teknik, Universitas Diponegoro \\ 2) Jurusan Biologi, Fakultas MIPA, Universitas Diponegoro \\ Jalan Prof. Sudharto, Tembalang, Semarang, Indonesia
}

\begin{abstract}
Abstrak - Salah satu teknologi pertanian yang belum termanfaatkan adalah penggunaan gelombang suara yang tepat untuk merangsang pembukaan stomata tanaman. Penelitian tentang pengaruh pemberian gelombang suara dalam meningkatkan kuantitas dan kualitas tanaman juga telah dilakukan di Indonesia. Pemberian pancaran gelombang suara berfrekuensi 3500 - 5500 Hertz pada beberapa tanaman agrokultura mampu meningkatkan hasil pipilan jagung kering 37,5\%, bawang merah 18,5\%, kentang 21,7\%, jahe gajah 88,4\%, jahe kapur 127\% dengan kenaikan kadar olcoresin 0,22\%, tembakau 31,8\% dengan peningkatan kadar nikolin 0,38\% serta peningkatan hasil kedelai 19\% dengan peningkatan kadar protein 7,3\%.

Alat terdiri atas perangkat keras dan perangkat lunak. Perangkat keras diimplementasikan dengan menggunakan mikrokontroler AVR Atmega328P yang mengintegrasikan sensor suhu DS18B20 dan RTC (real time clock) DS1302. Gelombang dibangkitkan oleh modul DDS (Direct Digital Synthesizer) AD9850 dengan frekuensi dapat diatur lewat program (programmable). Agar alat ramah lingkungan, pengisian daya aki/baterai berasal dari panel surya 10 Watt. Perangkat lunak dibuat menggunakan bahasa C dengan Arduino IDE yang kompatibel dengan mikrokontroler AVR.

Hasil pengujian menunjukkan alat mampu bekerja secara otomatis dalam membangkitkan gelombang suara dan mampu merangsang pembukaan stomata pada tanaman jagung.
\end{abstract}

Kata kunci : Teknologi Pertanian, Gelomabang Suara, Stomata, ATMega328p, Arduino

\section{PENDAHULUAN}

Sonic bloom suatu teknologi yang
memadukan pengaruh gelombang
berfrekuensi $3500-5000$ Hz. Teknologi sonic
bloom telah terbukti mampu meningkatkan
kuantitas dan kualitas hasil tanaman. Penerapan
sonic bloom pada tanaman jagung mampu
meningkatkan hasil pipilan kering, 37,5\%, bawang
merah 18,5\%, kentang 21,7\%, jahe gajah 88,4\%,
jahe kapur $127 \%$ dengan kenaikan kadar oleoresin
$0,22 \%$, tembakau $31,8 \%$ dengan peningkatan kadar
nikotin 0,3 8\% (Yulianto, H, Simanjuntak,
Sumardi, \& Utomo, 2004; Yulianto, 2008b).
Peningkatan hasil kedelai 19\% dengan peningkatan
kadar protein 7,3\% (Utomo, Sunarto, Supartoto,
Farid, \& Surjiti, 2002; Yulianto et al., 2004).
Peningkatan hasil yang terjadi pada berbagai
tanaman pangan yang diaplikasi sonic bloom,
memberikan harapan untuk menerapkan sonic
bloom sebagai alternatif teknologi terobosan guna
mendongkrak perandalan peningkalan produktivitas
padi di Indonesia. Aplikasi gelombang suara untuk menyuburkan pertumbuhan tanaman telah lama dilakukan. Singh pada tahun 1960 telah mengamati pengaruh aplikasi gelombang ini, Suara yang berbentuk musik "charukesi raga"dari alat gramafon pada pertanaman padi di Madras dan Teluk Bengal. Yang ternyata mampu meningkatkan hasil panen 25 - $60 \%$ lebih banyak daripada rata-rata hasil panen biasa di wilayah ini. Hlageselh awal 1973 menemukan bahwa tingkal perkecambahan lobak mengalami percepatan ketika diberi suara dengan frekuensi 4000 Herz (Ghofur, 2004).

Walaupun penggunaan teknik sonic bloom ini mampu meningkatkan hasil produksi pertanian dan perkebunan, namun saat ini penggunaannya di Indonesia masih tergolong sedikit. Hal ini disebabkan karena perangkat Sonic Bloom untuk membangkitkan gelombang suara masih impor, serta penggunaannya yang tidak praktis. Seperti penyalaan alat secara manual, menggunakan timer mekanik, sumber daya aki perlu diisi kembali, memerlukan peralatan eksternal termometer. Dari hal tesebut maka diperlukan inovasi untuk membuat alat Sonic Bloom yang praktis dan handal serta dapat diproduksi di dalam negeri. 


\subsection{Rumusan Masalah}

Berdasarkan latar belakang yang diuraikan di atas, maka permasalahan yang akan dibahas program ini adalah sebagai berikut:

1. Bagaimana membuat alat pembangkit gelombang suara yang dapat berjalan secara otomatis dalam penggunaannya?

2. Bagaimana agar alat tersebut dapat diatur frekuensinya sehingga dapat memenuhi kebutuhan yang spesifik untuk tiap tanaman?

3. Bagaimana agar alat tersebut efisien dan ramah lingkungan?

\subsection{Batasan Masalah}

Dalam pembuatan tugas akhir ini pembahasan masalah memiliki batasan pada permasalahan berikut :

1. Dalam pembuatan alat pembangkit suara ultrasonik ini, tidak dilakukan pengujian sejauh mana efek perangsangan pembukaan stomata tanaman menggunakan alat ini dalam jangka panjang.

2. Parameter pengujian keluaran alat pembangkit suara ultrasonik adalah alat dapat bekerja sesuai dengan yang diharapkan.

\subsection{Tujuan Penelitian}

Adapun tujuan yang akan dicapai dalam pembuatan tugas akhir ini adalah sebagai berikut.

1. Mengembangkan perangkat untuk mengaplikasikan teknologi mikrokontroler ke bidang pertanian.

2. Menyusun algoritma alat pembangkit suara ultrasonik.

3. Mengimplementasikan dan menguji alat pembangkit suara ultrasonik di Laboratorium Sistem Embedded dan Robotika Sistem Komputer Universitas Diponegoro dan di persawahan.

\section{DASAR TEORI}

Penelitian yang akan dilakukan berlandaskan pada berbagai teori yang memungkinkan tujuan penelitian dapat tercapai. Teori-teori tersebut menjadi dasar yang membangun penelitian dengan memberikan definisi dan penjabaran yang diperlukan dalam pelaksanaan penelitian, berikut Landasan Teori tersebut.

\subsection{Teknologi Sonic Bloom}

Penerapan teknologi sonicbloom dilakukan terhadap padi, bawang merah dan cabai merah melalui penelitian yang dapat memberikan peningkatan produktivitas rata-rata 42,6\% (Yulianto, 2006, 2008a, 2008b). Kualitas hasil tanaman pun meningkat berupa peningkatan kandungan gizi (Yulianto et al., 2004). Berikut parameter-parameter untuk pemberiaan gelombang suara pada tanaman.

1. Suara diberikan jika suhu dibawah $30^{\circ} \mathrm{C}$.

2. Suara diberikan selama $8-10$ jam perhari dari pukul 04.00 dan pukul 16.00.

3. Frekuensinya adalah antara $3500 \mathrm{~Hz}-5000$ $\mathrm{Hz}$

4. Diletakan di atas tiang agar jangkauan luas.

\subsection{Mikokontroler ATMega328P}

Mikrokontoler ATMega328P adalah mikrokontoler yang diproduksi oleh Atmel. Mikrokontroler ini memiliki 22 pin I/O, semua pin dapat berfungsi sebagai pin I/O digital, 6 pin dapat berfungsi sebagai keluaran PWM dan 6 pin dapat berfungsi sebagai pin I/O analog. Tegangan yang beroperasi untuk mikrokontroler ini adalah 2,7 - 5 Volt. Mikrokontroler ATmega328 memiliki 32 KByte memori flash untuk menyimpan kode sedangkan 2 KByte digunakan untuk bootloader. Mikrokontroler ATmega328 memiliki 2 KByte dari SRAM dan 1 KByte dari EEPROM yang dapat dibaca dan ditulis.

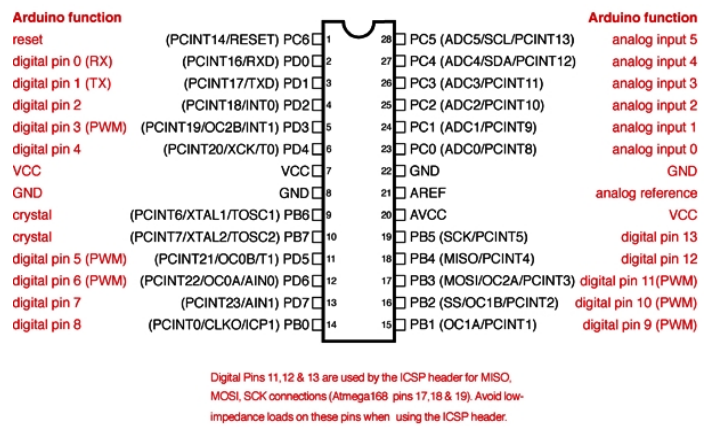

Gambar 1. Mikrokontroler ATMega328P

\subsection{Modul DDS (Direct Digital Synthesis)}

AD9850 DDS Signal Generator Modul adalah modul pembangkit gelombang yang menggunakan

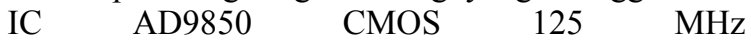
DDS Synthesizer produksi Analog Devices, Inc. IC ini menggunakan teknologi Digital-to-Analog Converter terkini yang berkinerja tinggi untuk mensintesa frekuensi (frequency synthesizer). Dengan osilator kristal aktif berfrekuensi $125 \mathrm{MHz}$ sebagai sumber detak berpresisi sangat tinggi, modul ini membangkitkan gelombang sinus analog murni dengan frekuensi yang dapat diprogram. Gelombang keluaran ini dapat digunakan langsung sebagai sumber frekuensi, atau dapat juga dikonversi menjadi gelombang kotak digital sebagai sumber pewaktu berakurasi tinggi yang responsif.

Spesifikasi:

1. Membangkitkan 2 gelombang sinus (sine wave) dan 2 gelombang kotak (square wave)

2. Presisi hingga frekuensi harmonik $20 \mathrm{MHz}$, $\max 40 \mathrm{MHz}$ (di atas $20 \mathrm{MHz}$, gelombang akan mengalami distorsi) 
3. Frekuensi maksimum gelombang kotak: 1 $\mathrm{MHz}$

4. Sudah memiliki low-pass filter $70 \mathrm{MHz}$

5. Menggunakan osilator aktif frekuensi tinggi $(125 \mathrm{MHz})$ dengan kualitas presisi yang sangat baik.

\subsection{Sensor Suhu DS18B20}

DS18B20 adalah sensor suhu digital yang dikeluarkan oleh Dallas Semiconductor. Dalam pembacaan suhu, sensor menggunakan protokol 1 wire communication. DS18B20 memilki 3 pin yang terdiri dari VCC, Ground dan Data Q. Tegangan yang beroperasi pada DS18B20 adalah 3-5 Volt dengan arus maksimal $1,5 \mathrm{~mA}$. Sensor suhu DS18B20 beroperasi pada suhu $-55^{\circ}$ celcius hingga $+125^{\circ}$ celcius. Keunggulan DS18B20 yaitu output berupa data digital dengan nilai ketelitian $0.5^{\circ}$ celcius selama kisaran suhu -10 celcius sampai +85 celcius sehingga mempermudah pembacaan oleh mikrokontroler.

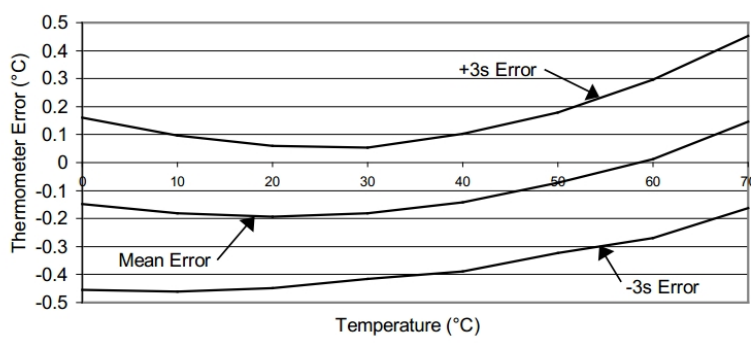

Gambar 2. Kurva pembacaan suhu DS18B20

\subsection{RTC (Real Time Clock) DS1302}

RTC adalah modul penghitung waktu dan penyimpan data waktu, dengan adanya komponen ini unit pengendali dapat melakukan pengendalian kerja sistem dengan waktu yang akurat. RTC memiliki kemampuan untuk menghitung waktu dengan tepat. Keunggulan-keunggulan yang dimiliki oleh RTC diantaranya :

1. Menghitung waktu mulai detik, menit, jam, tanggal, bulan, tahun, hari dalam minggu dengan kompensasi tahun kabisat sampai tahun 2100.

2. Kemampuan untuk selalu membaharui informasi waktu meskipun sumber utama terputus.

\subsection{Panel Surya}

Panel surya adalah perangkat rakitan sel-sel fotovoltanik yang mengkonversi sinar matahari menjadi listrik. Tegangan yang dihasilkan antara 17 - 22 Volt dan arusnya tergantung dari Wattpeak panel surya tersebut. Masa pakai panel surya dapat mencapai kurang lebih 25 tahun.

\section{PERANCANGAN SISTEM}

Dalam bab ini membahas spesifikasi kebutuhan fungional, spesifikasi kebutuhan nonfungsional, perancangan perangkat keras dan perancangan perangkat lunak.

\subsection{Spesifikasi Kebutuhan Fungsional}

Spesifikasi kebutuhan fungsional dilakukan untuk memberi gambaran tentang alat yang akan dibuat dapat berfungsi sesuai dengan yang diinginkan. Kebutuhan fungsional tersebut sebagai berikut:

1. Alat menggunakan mikrokontroler sebagai pusat kontrol untuk otomatisasi dalam pemberian gelombang suara.

2. Alat dapat membaca kondisi lingkungan sekitar, tegangan baterai dan informasi waktu untuk digunakan sebagai parameter dalam pemberian gelombang suara.

3. Pemberian gelombang suara pada tanaman dapat secara otomatis dengan suhu di bawah $30^{\circ} \mathrm{C}$, waktu yang telah diatur dan kapasistas baterai yang mencukupi.

4. Alat menyediakan antarmuka pengguna menggunakan LCD 16x2 dan tombol untuk pengaturan dalam pemberian gelombang suara pada tanaman.

5. Pengisi ulang daya aki berasal dari energi terbarukan yaitu energi matahari menggunakan panel surya sehingga ramah lingkungan.

6. Penggunaan komponen yang mengonsumsi daya paling sedikit untuk efisiensi kosnsumsi daya.

\subsection{Spesifikasi Kebutuhan Non-Fungsional}

Kebutuhan non-fungsional mendeskripsikan tingkatan dari kualitas misalnya dapat digunakan atau tidak. Kebutuhan non-fungsional dari pembuatan tugas akhir ini adalah purwarupa alat dibuat sedemikian rupa sehingga memudahkan dalam proses pemasangan dan penggunaannya.

\subsection{Perancangan Perangkat Keras}

Kebutuhan non-fungsional mendeskripsikan tingkatan dari kualitas. Kebutuhan non-fungsional dari pembuatan tugas akhir ini adalah sebagai berikut:

1. Purwarupa alat dibuat sedemikian rupa sehingga memudahkan dalam proses pemasangan dan penggunaannya.

2. Kontruksi purwarupa alat terbuat dari akrelik agar komponen yang berada didalam tidak terganggu oleh kondisi diluar

3. Penyangga purwarupa alat terbuat dari besi agar dapat diletakan pada tiang dan dapat menopang keseluruhan komponen. 


\subsubsection{Digram blok alat}

Diagram blok perancangan alat dapat dilihat pada Gambar 3.1.

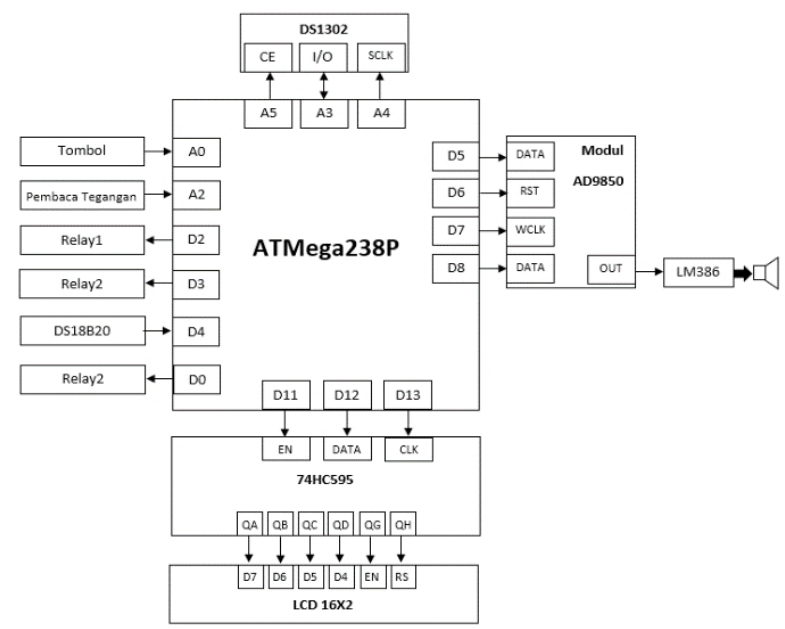

Gambar 3. Diagram Blok Alat

3.2.1 Perancangan desain papan sirkuit elektronik

Perancangan papan sirkuit elektronik dibutuhkan untuk menghubungkan komponenkomponen elektronika yang dibutuhkan untuk membuat purwarupa alat.

Papan sirkuit elektronik terlebih dahulu dirancang menggunakan perangkat lunak bernama EAGLE (Easily Applicable Graphical Layout Editor). Papan sirkuit terdiri dari 2 papan sirkuit yaitu papan sirkuit utama dan papan sirkuit LCD.
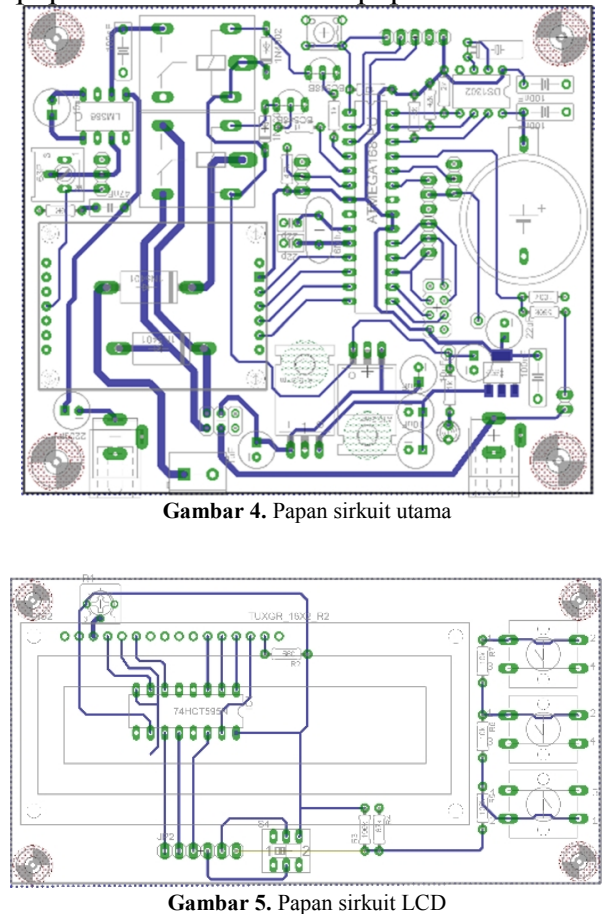

\subsubsection{Perancangan Perangkat Lunak}

Perancangan perangkat lunak digunakan untuk memberikan tahapan yang jelas dalam pembuatan program yang akan mengendalikan perangkat keras. Perancangan perangkat lunak terdiri dari perancangan program utama, perancangan fungsi $\mathrm{BUNYI}()$, perancangan pengisian ulang daya, perancangan fungsi TOMBOL() dan perancangan alur tegangan

\section{Perangcangan program utama}

Perancangan program utama merupakan perancangan program yang dibutuhkan oleh mikrokontroller ATMega328P sebagai pusat. Perancangan ini bertujuan untuk pengoperasian alat secara otomatis. Perancangan ini berdasarkan pada penelitian yang dilakukan oleh yulianto tentang pemberian gelombang suara pada tanaman (Yulianto, 2006, 2008a, 2008b). Berikut merupakan diagram alir program utama.

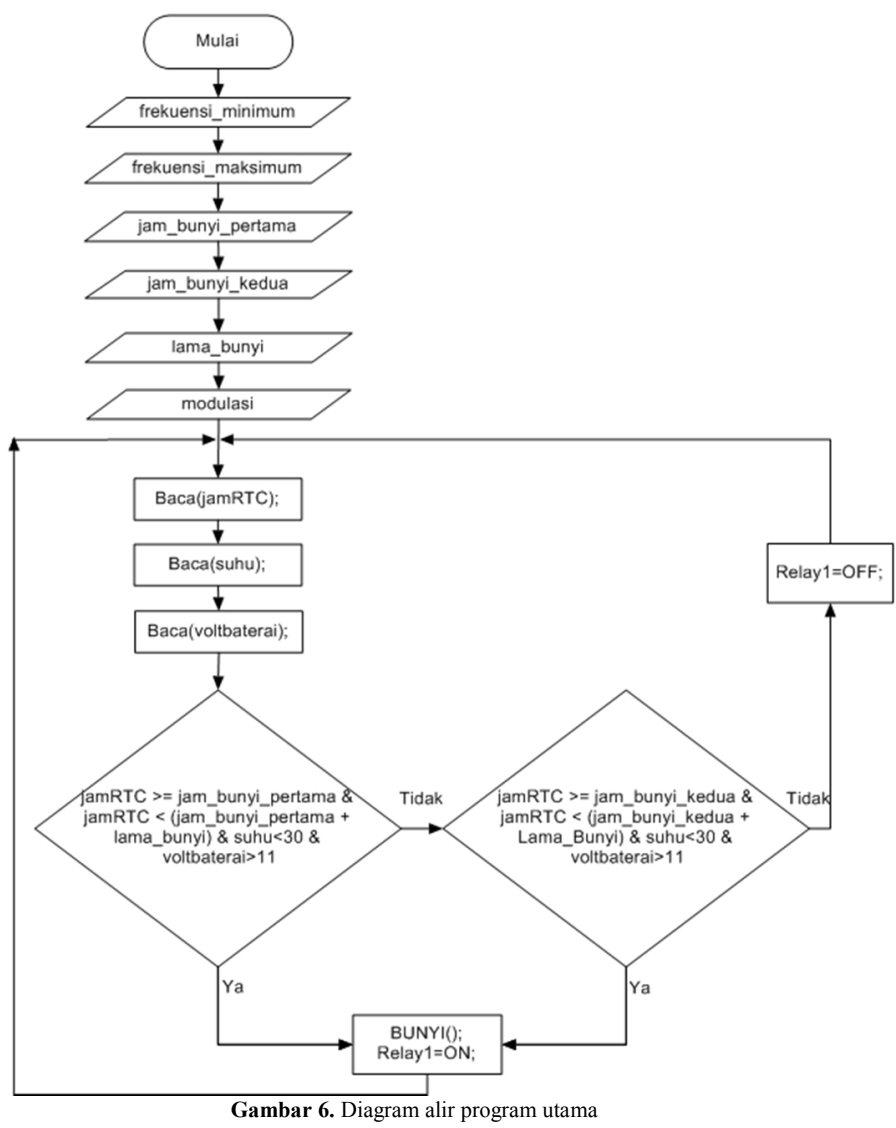

Pada Gambar 3.19 menunjukkan digram alir program utama. Pertama, nilai frekuansi_minimum, frekuensi maksimum, jam_bunyi_pertama, jam_bunyi_kedua, lama_bunyi, dan modulasi terlebih dahulu diatur oleh pengguna melalui antarmuka LCD. Kemudian membaca informasi waktu, suhu dan tegangan baterai. Setelah itu, membandingkan nilai jam_bunyi_pertama atau jam_bunyi_kedua dengan jamRTC, nilai pembacaan suhu dan nilai pembacaan tegangan. Apabila perbandingan nilai jam_bunyi_pertama atau jam_bunyi_kedua dengan jamRTC bernilai TRUE, suhu di bawah $30^{\circ} \mathrm{C}$ dan voltbaterai lebih dari 11 
Volt maka RELAY1 akan ON dan alat akan membangkitkan frekuensi dengan fungsi BUNYI(). Apabila perbandingan tersebut bernilai FALSE RELAY1 akan OFF dan selanjutnya kembali ke langkah pembacaan waktu RTC.

5. Perancangan fungsi BUNYI()

Berikut merupakan digram alir fungsi BUNYI() untuk membangkitkan gelombang suara secara modulasi.

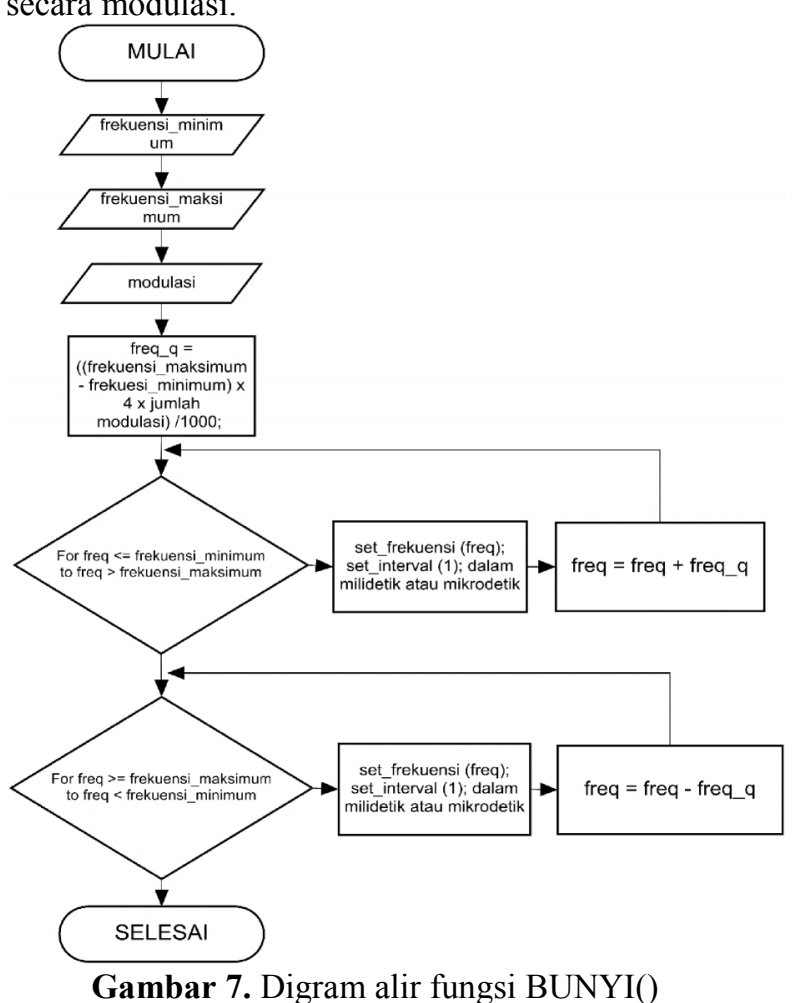

Pada Gambar 7 menunjukkan diagram alir fungsi BUNYI(). Langkah pertama yaitu, mengatur nilai frekuansi_minimum, frekuensi maksimum dan modulasi. Berikut rumus perhitungan nilai freq_q yang digunakan untuk membangkitkan gelombang suara secara modulasi.

$$
\text { freq } \mathrm{q}=\frac{\text { (frekuensi_maksimum }- \text { frekuensi_minimum) } \times 2 \times \text { modulasi }}{1000}
$$

Pada rumus di atas hasil perhitungan frekuensi_maksimum dikurangi dengan frekuensi_minimum membentuk setengah gelombang. Sebagai gambarannya dapat dilihat pada Gambar 8.

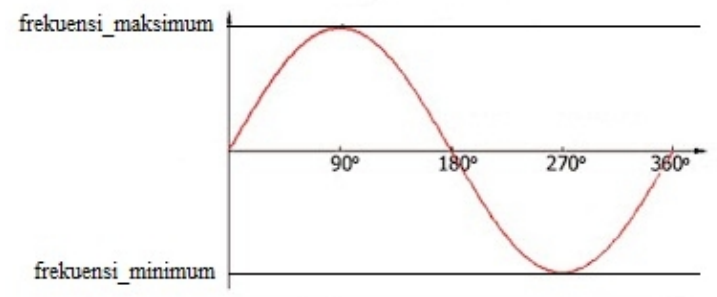

Gambar 8. Gelombang sinus
Kemudian untuk membentuk satu gelombang penuh maka setengah gelombang tersebut harus dikali dengan 2. Setelah membetuk satu gelombang penuh selanjukan hasil perhitungan tersebut dikali dengan modulasi. Pada program digunakan interval dalam 1 milidetik maka dalam 1 detik dapat melakukan 1000 perhitungan atau 1000 Herz. Sehingga hasil dari perhitungan frekuensi_maksimum dikurangi dengan frekuensi_minimum dikali dengan 2 dan dikali modulasi harus dibagi dengan 1000.

Setelah nilai freq $q$ diketahui maka akan melakukan perulangan dari nilai frekuansi_minimum menuju nilai frekuensi_maksimum. Perulangan dilakukan dengan cara menambahkan nilai freq_q ke nilai frekuansi_minimum dengan interval 1 milidetik.

$$
\text { freq }=\text { freq }+ \text { freq_q }
$$

Selanjutnya melakukan perulangan kembali dari nilai frekuensi_maksimum menuju frekuansi_minimum. Perulangan dilakukan dengan cara mengurangi nilai frekuansi_minimum dengan nilai freq_q dengan interval 1 milidetik.

$$
\text { freq }=\text { freq - freq_q }
$$

6. Perancangan fungsi TOMBOL ( )

Berikut merupakan diagram alir untuk menampilakan menu pada LCD 16×2.
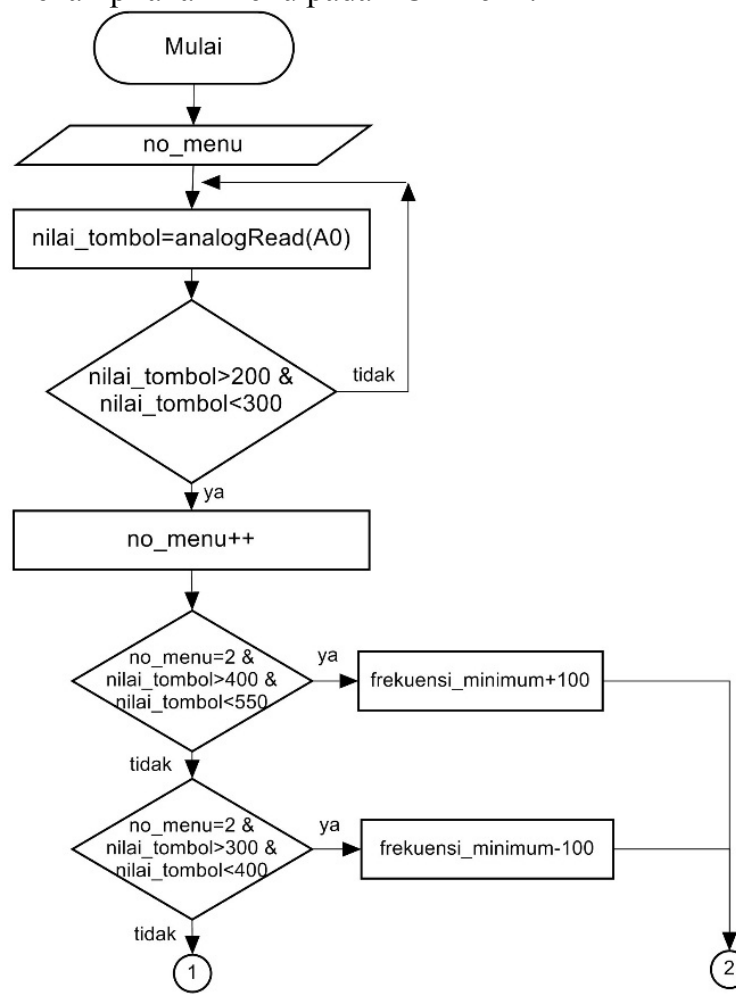

Gambar 9. Diagram alir fungsi MENU() 


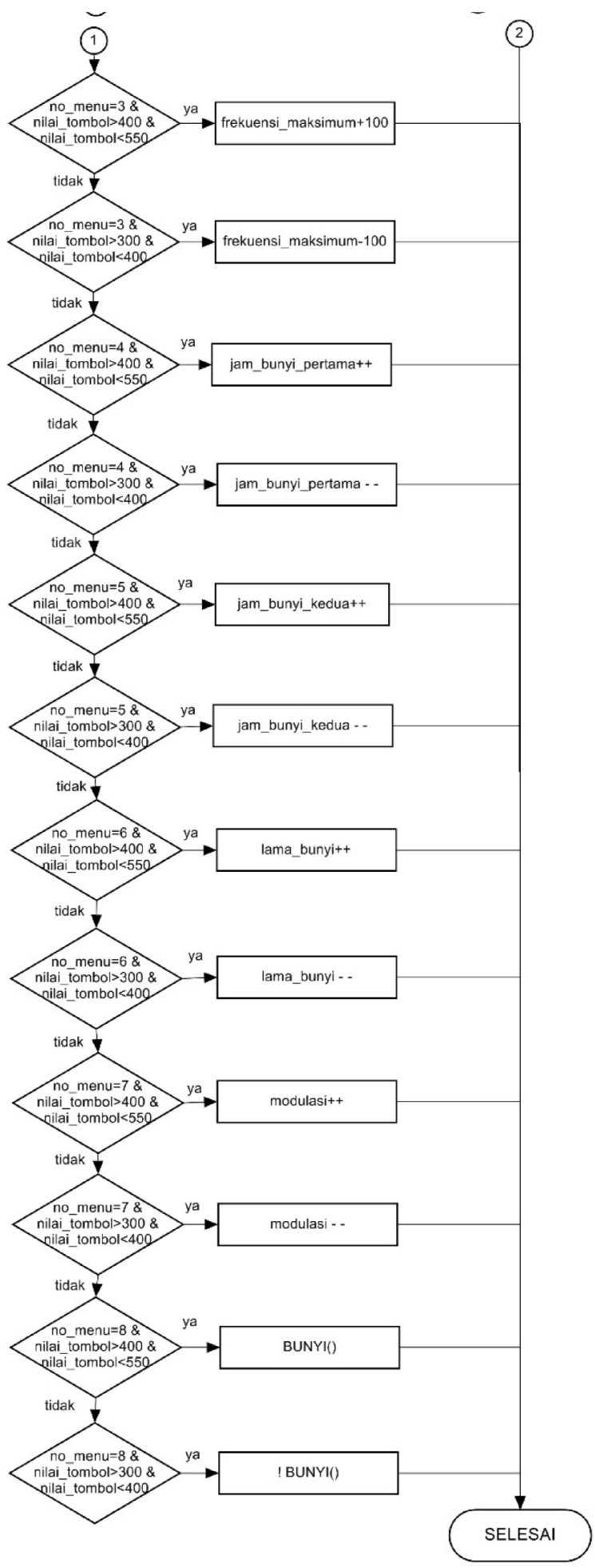

Gambar 10. Diagram alir fungsi $\mathrm{MENU}()$

Gambar 9 dan Gambar 10 menunjukkan diagram alir proses memilih menu. Antarmuka menu mengunakan LCD 16x2 dan tombol digunakan untuk interaksi alat dengan pengguna. Pengguna dapat melihat informasi keadaan alat dan dapat mengatur frekuensi_minimum, frekuensi maksimum, jam_bunyi_pertama, jam_bunyi_kedua, lama bunyi dan modulasi. Pengoperasian menu dilakukan dengan tiga buah tombol.

Tabel 1. Fungsi tiap tombol

\begin{tabular}{|c|l|c|}
\hline No & \multicolumn{1}{|c|}{ Tombol } & Fungsi \\
\hline 1 & Atas & Memilih menu \\
\hline 2 & Tengah & Menambah nilai \\
\hline 3 & Bawah & Mengurangi nilai \\
\hline
\end{tabular}

7. Perancangan pengisian ulang daya aki

Berikut merupakan diagram alir untuk pengisian ulang daya aki/baterai dari panel surya.

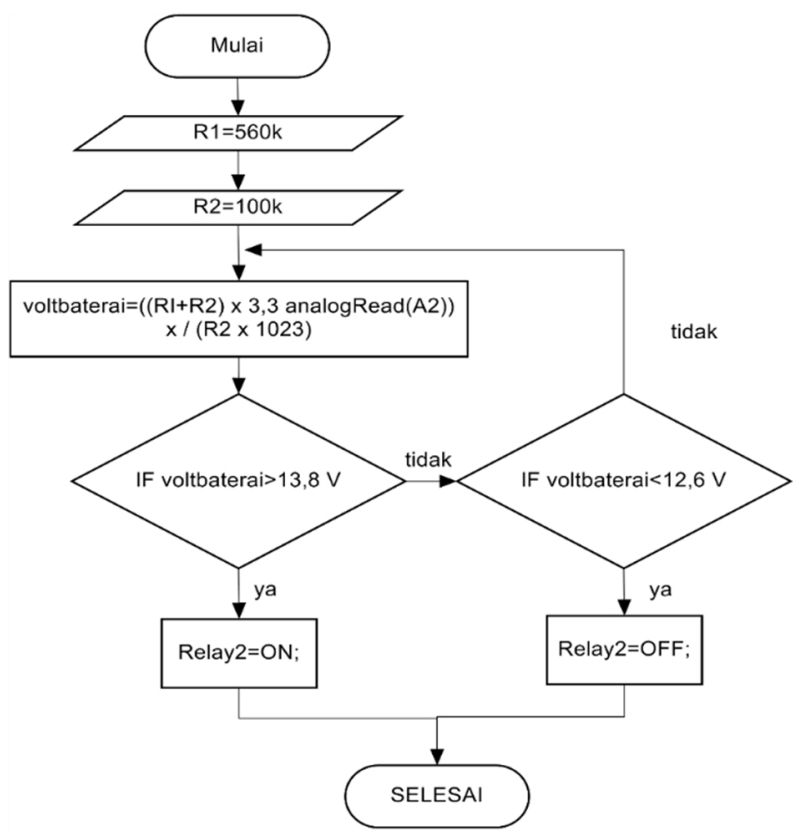

Gambar 11. Diagram alir pengisian ulang daya aki

Pada Gambar 11 menunjukan diagram alir untuk pengisian ulang daya aki/baterai dari panel surya. Pembacaan tegangan menggunakan motode pembagi tegangan. Nilai R1 sebesar $560 \mathrm{kohm}$ dan nilai R2 sebesar $100 \mathrm{kohm}$. Berikut rumus perhitungan untuk menghitung voltbaterai.

$$
\text { voltbaterai }=\frac{(\mathrm{R} 1+\mathrm{R} 2) \times \text { analog Refference } \mathrm{x} \text { analogRead(A2) }}{\mathrm{R} 2 \times 1023}
$$

Perhitungan pembacaan tegangan yaitu nilai nilai volt dikali dengan nilai analog refference yaitu $3, \overline{3}$ dan nilai R1 yang ditambah dengan nilai R2. Setelah itu dibagi dengan nilai R2 yang dikali dengan 1023. Berikut adalah hasil penyerdanaan perhitungan voltbaterai.

$$
\text { voltbaterai }=\frac{21,78 \times \text { AnalogRead (A2) }}{1023}
$$

Setelah melakukan perhitungan nilai voltbaterai selanjutnya membandingkan hasil tersebut dengan kondisi baterai dalam keadan penuh yaitu 13,8 volt. Apabila perbadingan tersebut bernilai TRUE maka RELAY2 akan ON. Apabila perbadingan tersebut bernilai FALSE maka akan membandingkan nilai voltbaterai kembali. 
Apabila tegangan baterai turun mejadi 12,6 maka RELAY2 akan OFF. Apabila perbadingan tersebut bernilai FALSE maka akan kembali ke langkah pembacaan nilai voltbaterai.

\section{Perancanga alur tegangan}

Percangan ini memberi gambaran tegangan yang beroperasi pada tiap komponen. Berikut merupakan diagram blok alur tegangan pada alat.

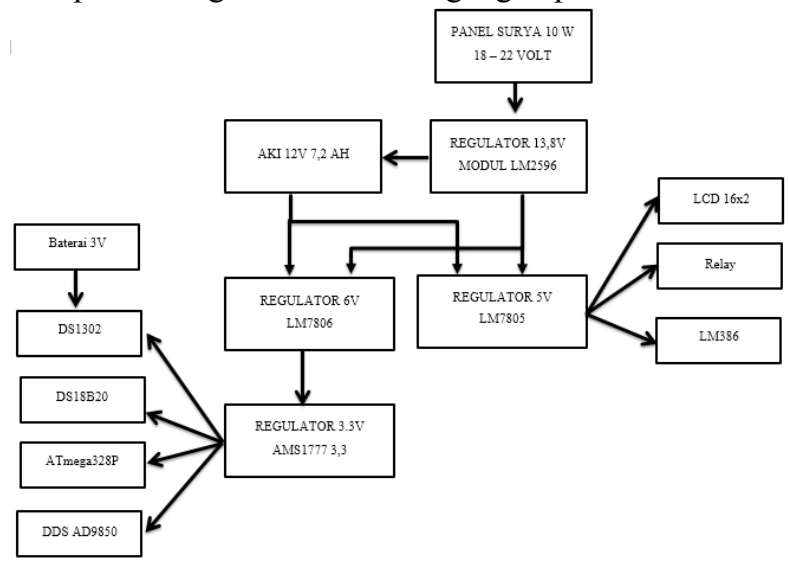

Gambar 12. Diagram blok alur tegangan

Gambar 12 menunjukan diagram blok alur tegangan pada alat. Komponen dengan tegangan 3,3 volt terdiri dari IC DS1302, IC DS18B20, mikrokontroler ATMega328P dan IC AD9850. Tegangan tersebut digunakan untuk efisiensi dalam komsumsi daya. Kemudian komponen dengan tegangan 5 volt terdiri dari LCD 16x2, LM386 dan Relay.

\section{IMPLEMENTASI DAN PENGUJIAN.}

Perangkat keras pertama yang diimplementasikan adalah pembuatan papan sirkuit elektronik berdasarkan skematik dari gambar rangkaian papan sirkuit elektronik yang telah dibuat sebelumnya. Papan sirkuit elektronik menjadi tempat komponen-komponen saling terhubung untuk menjadi sebuah perangkat keras yang dibutuhkan.

\subsection{Implementasi Perangkat Keras dan Perangkat Lunak}

Perangkat keras yang telah dirancang sebelumnya akan diimplementasikan, mulai dari pembuatan perangkat lunak hingga pemasangan perangkat keseluruhan alat. Hasil implementasi perangkat keras disajikan pada Gambar 13.

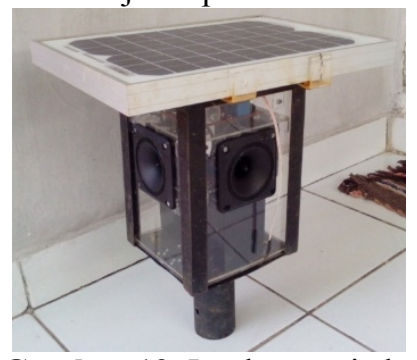

Gambar 13. Implemetasi alat

\subsection{Pengujian tegangan}

Pengujian ini bertujuan untuk memastikan tegangan yang diterima setiap komponen sesuai dengan spesifik tegangan masukan komponen. Pengujian dilakukan dengan alat ukur digital multitester SANWA 800a yang dimiliki oleh Laboratorium Embeded dan Robotika Teknik Sistem Komputer Universitas Diponegoro. Berikut hasil pengujian tegangan tiap komponen.

Tabel 2. Pengujian tegangan

\begin{tabular}{|l|l|c|}
\hline No & \multicolumn{1}{|c|}{ Komponen } & Tegangan (Volt) \\
\hline 1 & Papan sirkuit utama & $10-13,8$ \\
\hline 2 & ATMega328P & 3,3 \\
\hline 3 & DS1302 & 3,3 \\
\hline 4 & Baterai 2032 & 3,3 \\
\hline 5 & Modul AD9850 & 3,3 \\
\hline 6 & DS13B20 & 3,3 \\
\hline 7 & LM386 & 5 \\
\hline 8 & Relay & 5 \\
\hline 9 & 74HC595 & 5 \\
\hline 10 & LCD 16x2 & 5 \\
\hline
\end{tabular}

Pada Tabel 2 menunjukkan tegangan pada papan sirkuit bervariasi dari $12-13,8$ Volt. Pada saat panel surya menghasilkan daya listrik maka daya tersebut di konversikan terlebih dahulu menjadi 13,8 Volt dan dihubungkan dengan papan sirkuit utama untuk mengisi ulang daya aki/baterai.

\subsection{Pengujian daya alat}

Pengujian ini bertujuan untuk mengetahui berapa besar daya yang dikosumsi oleh alat dengan kondisi yang bervariasi dan daya yang dihasilkan oleh panel surya. Pengujian dilakukan dengan menggunakan alat ukur yaitu multitester digital.

\section{Daya yang dikonsumsi}

Pengujian ini bertujuan untuk mengetahui berapa besar daya yang dikosumsi oleh alat. Hasil pengujian daya yang dikonsumsi oleh alat dapat dilihat pada Tabel 3.

Tabel 3. Pengujian daya yang dikonsumsi

\begin{tabular}{|l|l|c|c|c|}
\hline No & \multicolumn{1}{|c|}{ Kondisi } & $\begin{array}{c}\text { Arus } \\
(\mathrm{mA})\end{array}$ & $\begin{array}{c}\text { Tegang } \\
\text { an (V) }\end{array}$ & $\begin{array}{c}\text { Daya } \\
(\mathrm{mW})\end{array}$ \\
\hline 1 & Alat standby & 38 & 12,5 & 475 \\
\hline 2 & $\begin{array}{l}\text { Alat standby } \\
\text { dengan LCD } \\
\text { aktif }\end{array}$ & 39 & 12,5 & 487 \\
\hline 3 & $\begin{array}{l}\text { Alat } \\
\text { membangkitk } \\
\text { an gelombang } \\
\text { suara }\end{array}$ & 170 & 12,5 & 2125 \\
\hline 4 & $\begin{array}{l}\text { Alat } \\
\text { membangkitk } \\
\text { an gelombang } \\
\text { suara dengan } \\
\text { LCD aktif }\end{array}$ & 176 & 12,5 & 2200 \\
\hline
\end{tabular}


Pada Tabel 3 menunjukkan alat dalam keadaan standby mengkonsumsi daya sebesar 475 $\mathrm{mW}$ atau 0,475 Watt. Pada saat alat membangkitkan suara dengan volume kekerasan maksimal mengonsumsi daya sebesar $2.125 \mathrm{mWatt}$ atau 2,125 Watt.

2. Daya yang dihasilkan

Pengujian ini bertujuan untuk mengetahui berapa besar daya yang dihasilkan oleh panel surya. Hasil pengujian daya yang dihasilkan dapat dilihat pada Tabel 4.

Tabel 4. Daya yang dihasilkan

\begin{tabular}{|l|l|c|c|c|}
\hline No & \multicolumn{1}{|c|}{ Kondisi } & $\begin{array}{c}\text { Arus } \\
(\mathrm{mA})\end{array}$ & $\begin{array}{c}\text { Tegang } \\
\text { an (V) }\end{array}$ & $\begin{array}{c}\text { Daya } \\
(\mathrm{mW})\end{array}$ \\
\hline 1 & $\begin{array}{l}\text { Output Panel } \\
\text { Surya }\end{array}$ & 320 & 20,4 & 6528 \\
\hline 2 & $\begin{array}{l}\text { Output Modul } \\
\text { LM2596 }\end{array}$ & 470 & 13,8 & 6486 \\
\hline
\end{tabular}

Pada Tabel 4 menunjukan daya yang dihasilkan panel surya sebesar 6.486 mWatt atau 6,486 Watt.

\subsection{Pengujian pembacaan suhu DS18B20}

Pengujian ini bertujuan pengujian untuk memastikan ketepatan dalam pembacaan sensor suhu DS18B20. Pengujian dilakukan dengan membandingkan sensor suhu DS18B20 dengan alat ukur digital Lutron LM-8100 yang dimiliki oleh Laboratorium Teknik Lingkungan Universitas Diponegoro. Hasil pengujian dapat dilihat pada Gambar 14.

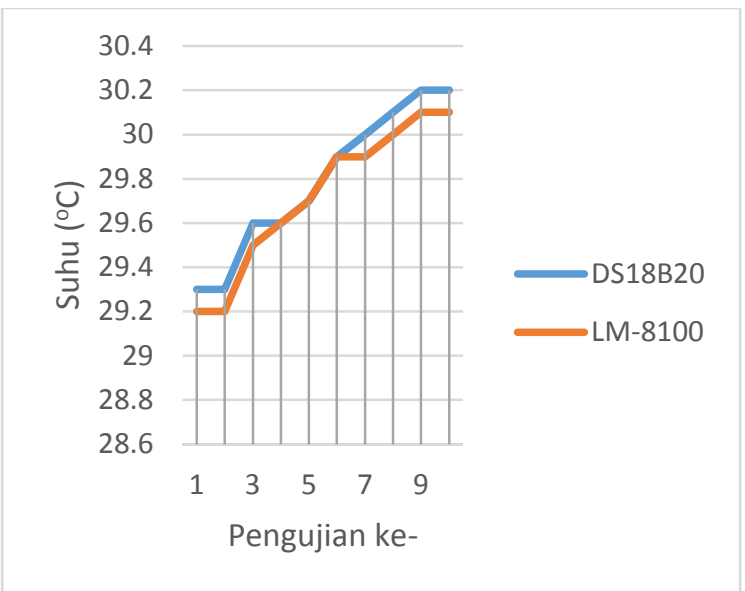

Gambar 14. Grafik perbandingan pembacaan suhu

Pada Gambar 14 menunjukkan pembandingan pembacaan suhu antara sensor suhu DS18B20 dengan alat ukur digital Lutron LM-8100. Pada pengujian tersebut didapat suatu nilai kesalahan pembacaan DS18B20 terhadap Lutron LM-8100 adalah sebesar $0,1{ }^{\circ} \mathrm{C}$.

\subsection{Pengujian RTC DS1302}

Pengujian ini bertujuan untuk memastikan ketepatan dalam waktu pembacaan waktu RTC DS1302. Pengujian dilakukan dengan membandingkan pembaca waktu RTC DS1302 dengan jam digital laptop selama 5 jam. Parameter awal yaitu waktu di RTC 16:0:0 dan waktu di laptop 15:58:51 dengan $\Delta t 0=69$.

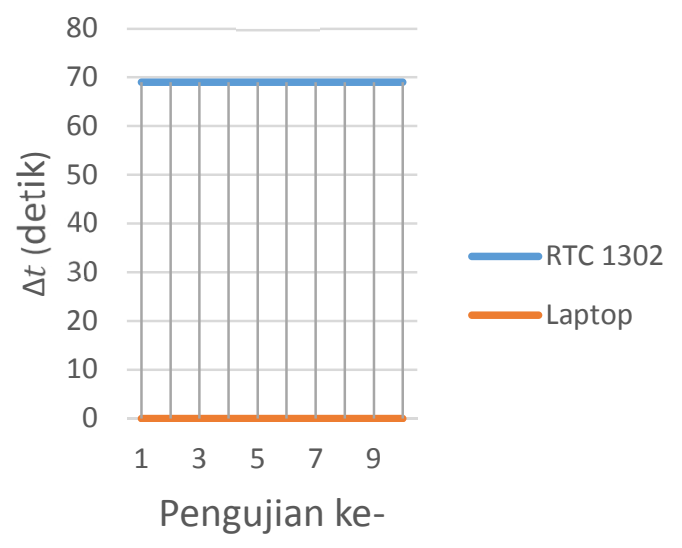

Gambar 15. Grafik perbandingan pembacaan suhu

Pada Gambar 15 menunjukkan perbandingkan pembaca waktu RTC 1302 dengan jam digital laptop. Kesalahan pembacaan waktu dari RTC DS1302 adalah jumlah rata-rata $\Delta t-\Delta t 0=$ $69-69=0$. Dari hasil tersebut menunjukkan waktu pada RTC DS1302 tidak mengalami pergeseran waktu.

\subsection{Pengujian pembacaan tegangan}

Pengujian ini bertujuan untuk memastikan ketepatan dalam pembacaan tegangan. Pengujian dilakukan dengan membandingkan pembaca tegangan pada sirkuit dengan alat ukur digital multitester SANWA 800a yang dimiliki oleh Laboratorium Embeded dan Robotika Teknik Sistem Komputer Universitas Diponegoro. Berikut hasil pengujian dapat dilihat pada Gambar 16.

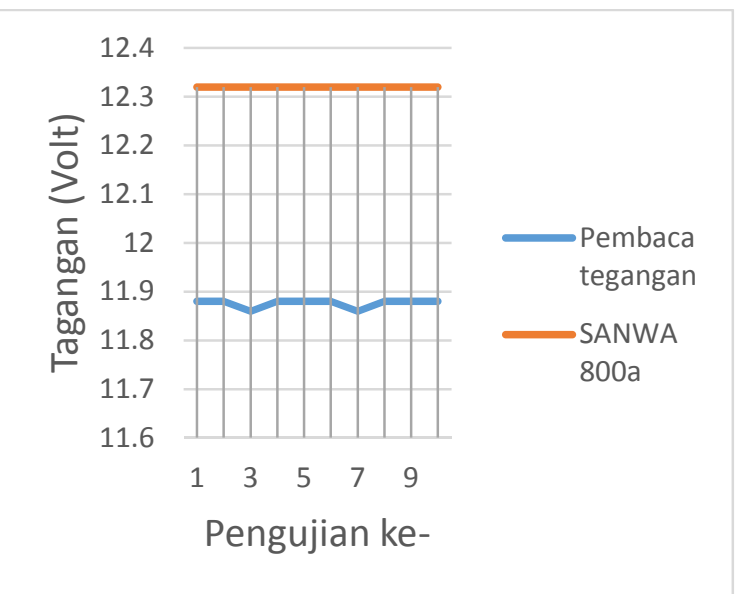

Gambar 16. Grafik perbandingan pembacaan suhu 
Pada Gambar 16 menunjukkan perbandingkan pembaca tegangan pada sirkuit dengan alat ukur digital multitester SANWA 800a . Kesalahan pembacaan tegangan dengan menggunakan teknik pembagi tegangan yaitu - 0,44 atau 3,57\%. Toleransi pada resistor yang disimbolkan mempunyai nilai toleransi $\pm 5 \%$. Sehingga untuk pembacaan tagangan secara tepat maka pada kode program utama perlu ditambah sebesar $3,57 \%$.

\subsection{Pengujian frekuensi}

Pengujian ini bertujuan untuk mengetahui apakah frekuensi yang dibangkitkan dalam kode sumber sesuai dengan frekuensi yang dibangkitkan dengan perangkat lunak bernama Spectrum Analyzer. Pengujian ini dilakukan dengan cara konektor keluaran dari amplifier dihubungkan ke konektor mix. Parameter frekuensinya yaitu frekuensi minimum $3500 \mathrm{~Hz}$ dan frekuensi maksimum $5500 \mathrm{~Hz}$. Berikut hasil pengujian dapat dilihat pada Gambar 17.

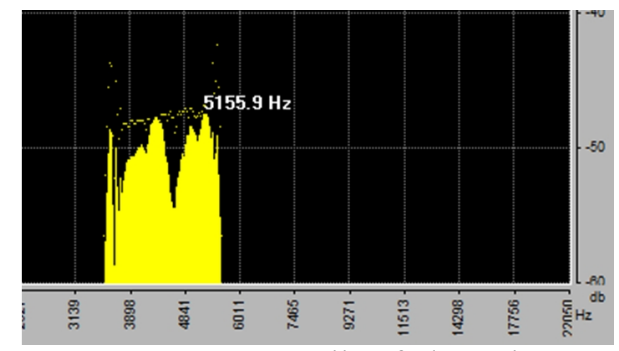

Gambar 17. Pengujian frekuensi

Pada Gambar 17 menunjukkan frekuensi yang dibangkitkan dalam kode sumber sesuai dengan analisis software Spectrum Analyzer.

\subsection{Pengujian implementasi alat}

Pengujian implementasi alat berupa pemasangan alat di sawah. Pengujian dilakukan di desa Krajan Kidul Kel. Kaliwadas Kec. Bumiayu Kab. Brebes Jawa Tengah. Pengujian ini bertujuan untuk menguji apakah alat dapat berjalan sesuai dengan yang diinginkan apabila diimplementasikan di lapangan. Pengaturan waktu membangkitkan gelombang suara yaitu jam $4-8$ pagi dan jam $4-8$ sore. Alat diletak di tiang setinggi 3 meter seperti terlihat pada Gambar 18.

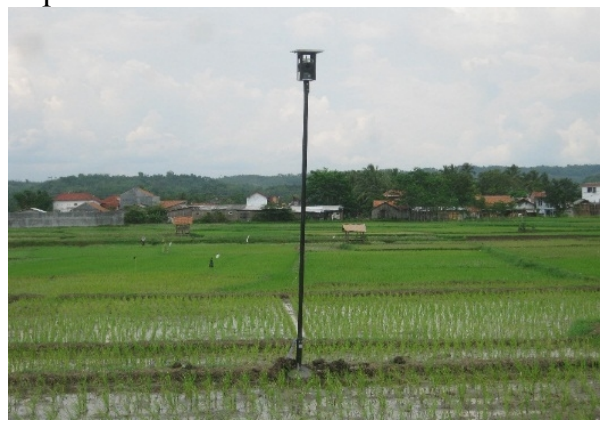

Gambar 18. Implementasi alat di Sawah
Hasil pengujian implentasi di Sawah, alat dapat bekerja dengan semestinya sesuai dengan pameter berikut:

1. Alat dapat membangkitkan gelombang suara secara otomatis dengan suhu di bawah $30^{\circ} \mathrm{C}$, waktu yang telah diatur dan kapasistas baterai yang mencukupi.

2. Alat dapat berhenti membangkitkan suara ultasonik sesuai dengan waktu yang telah diatur oleh pengguna.

3. Alat alat behenti membangkitkan suara ultasonik apabila suhu di atas $30^{\circ} \mathrm{C}$ walaupun pada waktu membangkitkan gelombang suara yang telah diatur oleh pengguna.

4. Aki/baterai pada alat dapat terisi ulang dayanya yang berasal dari daya panel surya.

\subsection{Pengujian efek terhadap stomata tanaman}

Pengujian ini berupa memberikan gelombang suara pada tanaman menggunakan alat ini. Kemudian daun dari tanaman tersebut diteliti dengan mikroskop untuk mengetahui apakah stomata membuka atau tidak. Pengujian ini menggunakan tanaman jagung. Tanaman yang digunakan dalam pengujian ini yaitu tanaman jagung. Pengujian dilakukan selama satu minggu. Pemberian gelombang suara dilakukan pada pukul 04.00 sampai 08.00 dan pada pukul 16.00 sampai pukul 20.00 Pengamatan stomata daun dilakukan setelah pemberian gelombang suara selesai. Hasil dari pengujian ini dapat dilihat pada Gambar 19 dan Gambar 20.

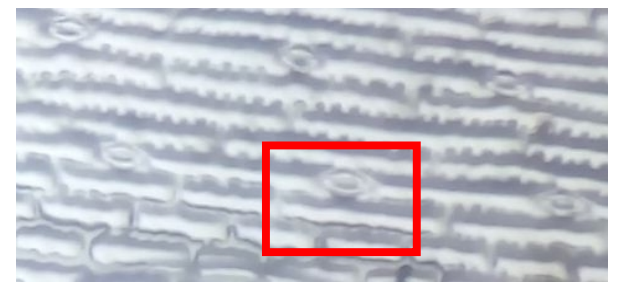

Gambar 19. Daun tanpa pemberian suara ultrasonik

Pada Gambar 19 menunjukan bahwa stomata pada daun tidak membuka apabila tidak diberi gelombang suara menggunakan alat ini.

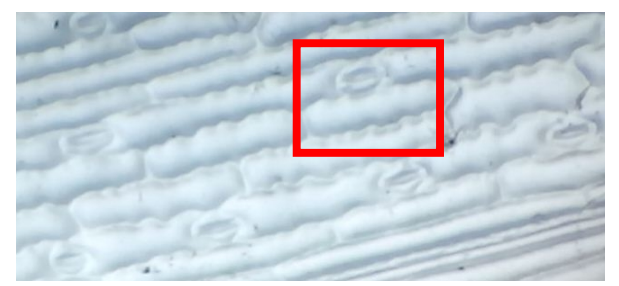

Gambar 20. Daun dengan pemberian suara ultrasonik

Pada Gambar 20 menunjukan bahwa stomata pada daun dapat membuka dengan pemberian suara ultrasonik menggunakan alat ini. 


\subsection{Kesimpulan}

\section{PENUTUP}

Dari hasil pengujian dan analisis alat pembuata tugas akhir ini maka dapat diambil kesimpulan sebagai berikut:

1. Alat dapat secara otomatis membangkitkan gelombang suara sesuai parameter yang telah diatur oleh pengguna.

2. Frekuensi untuk pemberian gelombang suara pada tanaman melalui antarmuka LCD 16x2 dan tombol.

3. Pembacaan kesalahan pembacaan tegangan sebesar 3,57\% dan kesalahan pembacaan suhu sebesar $0.1^{\circ} \mathrm{C}$.

4. Konsumsi daya alat pada saat standby sebesar 0,475 Watt dan konsumsi pada saat alat membangkitkan suara sebesar 2,125 Watt.

5. Alat pembangkit gelombang suara otomatis ini dapat bekerja dengan baik dalam implementasi di lapangan.

6. Alat pembangkit gelombang suara otomatis ini mampu merangsang stomata pada tanaman jagung untuk membuka.

7. Penggunaan energi terbarukan yaitu menggunakan panel surya untuk pengisi ulang daya aki menjadikan alat ramah lingkungan.

8. Penggunaan komponen yang mengonsumsi daya paling sedikit menjadikan alat efisien dalam konsumsi daya.

\subsection{Saran}

Berdasarkan pengujian dan analisa terhadap alat dalam pembuatan tugas akhir ini, alat masih memerlukan penyempurnaan, karena itu diberikan beberapa saran sebagai berikut.

1. Alat ini dapat dikembangkan lebih lanjut untuk menyempurnakan dari sisi desain maupun komponen yang digunakan.

2. Penambahan fitur seperti kontrol dan monitoring dari jarak jauh.

3. Pengujian alat lebih lanjut untuk jenis tanaman yang lainnya.

\section{DAFTAR PUSTAKA}

Ghofur, S. A. (2004). Keajaiban tumbuhan, dan manusia pun terkesikap oleh rahasia Tuhan. Secret Life of The Plant, 402(Terjemahan dari Tompkinn, $\mathrm{P}$ and $\mathrm{C}$. Bird).

Utomo, Sunarto, Supartoto, Farid, N., \& Surjiti, A. (2002). Kaji Tindak Penerapan Teknologi Sonic Bloom untuk Meningkatkan Prodiksi Kedelai. In Seminar Penerapan Teknologi Sonic Bloom di Jawa Tengah (p. 12). Ungaran: BPTP Jateng.
Yulianto. (2006). Sonic Bloom Sebagai Alternatif Teknologì Terobosan Untuk Meningkatkan Produktivitas Padi. Agrosains, 8, 87-90.

Yulianto. (2008a). Penerapan Teknologi Sonic Bloom dan Pupuk Organik untuk Peningkatan Produksi Bawang Merah (Studi Kasus Bawang Merah di Brebes, Jawah Tengah). J. Argoland, $15,148-155$.

Yulianto. (2008b). Pengkajian dan Pengembangan Teknologi Gelombang Suara dan Nutrisi Rumput Laut pada Cabai Merah. J. Agroland, $15,1-6$.

Yulianto, H, B., Simanjuntak, Sumardi, \& Utomo. (2004). Sonic Bloom Sebuah Terobosan Menuju Pertaniaan Masa Depan. In RAKORNAS ICMI. Semarang. 